\title{
References of Part I
}

Benestad, R. E. Solar Activity and Earth's Climate. Praxis-Springer, Berlin, 2002.

Benestad, R. E., and G. A. Schmidt. Solar trends and global warming. Journal of Geophysical Research (Atmospheres), 114, 14101, 2009. 10.1029/2008JD011639.

Benestad, R. E., H. O. Hygen, R. van Dorland, J. Cook, and D. Nuccitelli. Agnotology: learning from mistakes. Earth System Dynamics Discussion, 4, 451-505, 2013. 10.5194/esdd-4-451-2013.

Carrington, R. C. Observations of the Spots on the Sun. Williams and Norgate, London, 1863.

Clette, F., L. Svalgaard, J. M. Vaquero, and E. W. Cliver. Revisiting the Sunspot Number. A 400-Year Perspective on the Solar Cycle. Space Science Reviews, 186, 35-103, 2014. 10.1007/s11214-014-0074-2.

Cook, B. I., K. J. Anchukaitis, J. O. Kaplan, M. J. Puma, M. Kelley, and D. Gueyffier. Pre-Columbian deforestation as an amplifier of drought in Mesoamerica. Geophysical Research Letters, 39(L16706), 2012.

Coughlin, K. T., and K. K. Tung. Misleading patterns in correlation maps. Journal of Geophysical Research (Atmospheres), 111, 24102, 2006. 10.1029/2006JD007452.

D’Arrigo, R., R. Seager, J. E. Smerdon, A. N. LeGrande, and E. R. Cook. The anomalous winter of 1783-1784: Was the Laki eruption or an analog of the 20092010 winter to blame? Geophysical Research Letters, 38(L05706), 2011.

Damon, P. E., and P. Laut. Pattern of strange errors plagues solar activity and terrestrial climate data. EOS, Transactions American Geophysical Union, 85(39), 370-374, 2004.

Eddy, J. A. The Maunder Minimum. Science, 192, 1189-1202, 1976. 10.1126/science.192.4245.1189.

Farrar, P. D. Are cosmic rays influencing oceanic cloud coverage-or is it only El Nino? Climatic Change, 47(1-2), 7-15, 2000.

Franklin, B. Meteorological imaginations and conjectures. In Manchester Literary and Philosophical Society Memoirs and Proceedings, vol. 2, 1784, 1784.

Friis-Christensen, E., and K. Lassen. Length of the solar cycle: an indicator of solar activity closely associated with climate. Science, 254, 698-700, 1991. 10.1126 /science.254.5032.698. 
Fröhlich, C. Total Solar Irradiance: What Have We Learned from the Last Three Cycles and the Recent Minimum? Space Science Reviews, 176(1-4), 237-252, 2013. $10.1007 / \mathrm{s} 11214-011-9780-1$.

Gray, L. J., J. Beer, M. Geller, J. D. Haigh, M. Lockwood, et al. Solar Influences on Climate. Reviews of Geophysics, 48, 4001, 2010. 10.1029/2009RG000282.

Herschel, W. Observations tending to investigate the nature of the Sun, in order to find the causes or symptoms of its variable emission of light and heat; with remarks on the use that may possibly be drawn from solar observations. Philosophical Transactions of the Royal Society of London, 95, 261-318, 1801.

Hodell, D. A., M. Brenner, J. H. Curtisa, and T. Guilderson. Solar forcing of drought frequency in the Maya Lowlands. Science, 292, 1367-1370, 2001.

Hoyt, D. V. The Smithsonian Astrophysical Observatory Solar Constant Program. Reviews of Geophysics, 17(3), 427-458, 1979. 10.1029/RG017i003p00427, URL http://dx.doi.org/10.1029/RG017i003p00427.

Hoyt, D. V., and K. H. Schatten. The Role of the Sun in Climate Change. Oxford University Press, Oxford, 1997.

Humlum, O., J.-E. Solheim, and K. Stordahl. Identifying natural contributions to late Holocene climate change. Global and Planetary Change, 79, 145-156, 2011. 10.1016/j.gloplacha.2011.09.005.

Kahneman, D. Thinking, Fast and Slow. Penguin, 2012.

Kornblueh, I. H. In memoriam Alexander Leonidovich Tchijevsky. International Journal of Biometeorology, 9(1), 99-99, 1965. 10.1007/BF02187321.

Kristjánsson, J. E., A. Staple, J. Kristiansen, and E. Kaas. A new look at possible connections between solar activity, clouds and climate. Geophysical Research Letters, 29, 22-1, 2002.

Labitzke, K., and H. van Loon. Associations between the 11-year solar cycle, the QBO (quasi-biennial-oscillation) and the atmosphere. Part I: the troposphere and stratosphere in the northern hemisphere in winter. Journal of Atmospheric and Terrestrial Physics, 50, 197-206, 1988.

Laken, B. A., E. Pallé, J. Čalogović, and E. M. Dunne. A cosmic ray-climate link and cloud observations. Journal of Space Weather and Space Climate, 2, A18, 2012.

Latarjet, R. Radiations in relation to carcinogenesis and mutation. In Genetics and Cancer. University of Texas Press, 1959.

Le Page, M. Sceptical climate researcher won't divulge key program. New Scientist, 18 December, 2009. 
Le Roy-Ladurie, E. Histoire du climat depuis l'an mil. Flammarion, Paris, 1967.

Lockwood, M., R. G. Harrison, T. Woollings, and S. K. Solanki. Are cold winters in Europe associated with low solar activity? Environmental Research Letters, 5(2), 024001, 2010. 10.1088/1748-9326/5/2/024001.

Love, J. J. On the insignificance of Herschel's sunspot correlation. Geophysical Research Letters, 40, 4171-4176, 2013.

Marsh, N. D., and H. Svensmark. Low cloud properties influenced by cosmic rays. Physical Review Letters, 85(23), 5004, 2000.

Meehl, G. A., J. M. Arblaster, K. Matthes, F. Sassi, and H. van Loon. Amplifying the Pacific Climate System Response to a Small 11-Year Solar Cycle Forcing. Science, 325, 1114-, 2009. 10.1126/science.1172872.

Pittock, A. B. Solar variability, weather and climate: an update. Quarterly Journal of the Royal Meteorological Society, 109, 23-55, 1983. 10.1256/smsqj.45902.

Scafetta, N., and B. J. West. Phenomenological reconstructions of the solar signature in the Northern Hemisphere surface temperature records since 1600. Journal of Geophysical Research (Atmospheres), 112, 24-+, 2007. 10.1029/2007JD008437.

Schwabe, H. Sonnen-Beobachtungen im Jahre 1843. Astronomische Nachrichten, 21(15), 234-235, 1844.

Sherwood, S. Science controversies past and present. Physics Today, 64(10), 39-44, 2011. 10.1063/PT.3.1295.

Solheim, J.-E., K. Stordahl, and O. Humlum. Solar Activity and Svalbard Temperatures. Advances in Meteorology, 2011, 8, 2011. URL http://dx.doi.org/ $10.1155 / 2011 / 543146 \%] 543146$.

Soon, W. W.-H., and S. H. Yaskell. The Maunder Minimum : the variable sunearth connection. World Scientific Publishing Co, Singapore, 2003.

Stager, J. C., A. Ruzmaikin, D. Conway, P. Verburg, and P. J. Mason. Sunspots, El Niño, and the levels of Lake Victoria, East Africa. Journal of Geophysical Research (Atmospheres), 112, 15106, 2007. 10.1029/2006JD008362.

Steinhilber, F., J. A. Abreu, J. Beer, I. Brunner, M. Christl, et al. 9,400 years of cosmic radiation and solar activity from ice cores and tree rings. Proceedings of the National Academy of Sciences, 109(16), 5967-5971, 2012. 10.1073/pnas.1118965109, http://www . pnas.org/content/109/16/5967. full. pdf+html, URL http://www . pnas .org/content/109/16/5967. abstract.

Stocker, T., and D. Qin, eds. Climate Change 2013 - The Physical Science Basis. Working Group I Contribution to the Fifth Assessment Report of the IPCC. Cambridge University Press, Cambridge, 2014. 
Svensmark, H., and E. Friis-Christensen. Variation of cosmic ray flux and global cloud coverage - a missing link in solar-climate relationships. Journal of Atmospheric and Solar-Terrestrial Physics, 59(11), 1225-1232, 1997.

Turner, B. L., and J. L. Sabloff. Classic Period collapse of the Central Maya Lowlands: Insights about human-environment relationships for sustainability. Proceedings of the National Academy of Sciences of the USA, 109, 13908-13914, 2012.

Usoskin, I. G. A History of Solar Activity over Millennia. Living Reviews in Solar Physics, 5, 3-67, 2008. 0810.3972, URL http://solarphysics.livingreviews. org/Articles/lrsp-2008-3/.

Vaquero, J. M., and M. Vázquez. The Sun Recorded Through History: Scientific Data Extracted from Historical Documents, vol. 361 of Astrophysics and Space Science Library. Springer Verlag, 2009.

Wilks, D. S. On "Field Significance" and the False Discovery Rate. Journal of Applied Meteorology and Climatology, 45, 1181-1189, 2006. 10.1175/JAM2404.1.

Wilks, D. S. Statistical Methods in the Atmospheric Sciences: an Introduction. International Geophysics. Academic Press, San Diego, 3rd edition, 2011. 